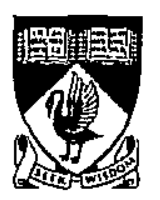

THE ASIAN FINANCIAL CRISIS AND NATURAL RATE OF UNEMPLOYMENT: ESTIMATES FROM A STRUCTURAL VAR FOR THE NEWLY INDUSTRIALIZING ECONOMIES OF ASIA

by

Nicolaas Groenewold

and

Sam Hak Kan Tang

DISCUSSION PAPER 01.12

DEPARTMENT OF ECONOMICS

THE UNIVERSITY OF WESTERN AUSTRALIA 35 STIRLING HIGHWAY

CRAWLEY, WA 6009

AUSTRALIA 


\title{
THE ASIAN FINANCIAL CRISIS AND NATURAL RATE OF UNEMPLOYMENT: ESTIMATES FROM A STRUCTURAL VAR FOR THE NEWLY INDUSTRIALIZING ECONOMIES OF ASIA*
}

by

\author{
Nicolaas Groenewold \\ Department of Economics \\ University of Western Australia \\ Crawley, WA 6009 \\ Sam Hak Kan Tang \\ Department of Economics \\ Chinese University of Hong Kong \\ Shatin, Hong Kong
}

DISCUSSION PAPER 01.12

\section{DEPARTMENT OF ECONOMICS}

THE UNIVERSITY OF WESTERN AUSTRALIA

35 STIRLING HIGHWAY

CRAWLEY, WA 6009

AUSTRALIA

\footnotetext{
* We are grateful to the Department of Economics at UWA and Chinese University of Hong Kong for financial support for this research and to Paul Branston for enthusiastic research assistance.
} 



\section{Introduction}

The "natural rate of unemployment" is an important concept in macroeconomics. Not only does it assume a central role in macroeconomic theory, policy-makers also explicitly employ such a concept in their implementation and evaluation of public policies. For example, the former financial secretary of Hong Kong, Mr. Donald Tsang Yam-kuen, recently commented that full employment in Hong Kong would be achieved if the unemployment rate reaches approximately 3 percent, as he reassured the people of Hong Kong that the economy was recovering from the Asian financial crisis of 1997-98. ${ }^{1}$

The newly industrializing economies (NIEs) of Asia have made a remarkable recovery from the crisis of 1997-98. As shown in Table 1, their real GDP growth is estimated to recover to their average pre-crisis levels by 2000 . However, despite the rapid recovery in their growth rates, there has been a growing concern that the unemployment rates of these so-called "dragon" economies is unlikely to return to their pre-crisis levels soon. For example, Hong Kong's unemployment rate remains at 4.6 percent in April 2001, which is much higher than the level of 2.4 percent in 1997 (see Table 1). Further, both South Korea (Korea) and Singapore still experience a rate of unemployment that is roughly two percentage points higher in 2000 than their historical levels. On the other hand, Taiwan's unemployment did not worsen significantly over the crisis period, but has been gradually increasing since the early 1990s.

Table 1: Real GDP Growth and Unemployment Rates (percent p.a.)

\begin{tabular}{|c|c|c|c|c|c|c|c|c|c|}
\hline Country & $\begin{array}{c}\text { 1970-96 } \\
\text { Average } \\
\text { GDP }\end{array}$ & \multicolumn{2}{|c|}{$\mathbf{1 9 9 7}$} & \multicolumn{2}{c|}{1998} & \multicolumn{2}{|c|}{1999} & \multicolumn{2}{c|}{2000} \\
\hline $\begin{array}{c}\text { Hong } \\
\text { Kong }\end{array}$ & 7.5 & 5.3 & 2.4 & -5.1 & 4.7 & 3.0 & 6.1 & 8.2 & 5.1 \\
\hline Korea & 8.4 & 5.0 & 2.6 & -6.7 & 6.9 & 10.7 & 6.2 & 8.6 & 4.2 \\
\hline Singapore & 8.2 & 8.0 & 1.8 & 0.4 & 3.3 & 5.4 & 3.5 & 9.1 & 3.5 \\
\hline Taiwan & 8.3 & 6.3 & 2.7 & 4.6 & 2.7 & 5.7 & 2.9 & 7.0 & 2.2 \\
\hline
\end{tabular}

Sources: Figures for 1970-96 are taken from The Economist (1998), 'Frozen Miracle', 7 March. Figures for other years are taken from The Econonist Intelligence Unit, 'Latest Country Analysis', various issues. An "'" denotes estimates.

What accounts for the different labor market experiences in these countries over the crisis period? Why does the unemployment rate refuse to return to pre-crisis

\footnotetext{
${ }^{1}$ His remark was reported on the HKTV evening news. Mr. Tsang predicted in late August 2000 that the unemployment rate would drop from five percent to three percent by the end of 2001. However, the unemployment rate in Hong Kong rose by 0.1 of a percent point to 4.6 percent in March 2001 (South China Morning Post, April 27 2001).
} 
levels despite the strong growth recovery? Is the rise in the unemployment rate a temporary phenomenon or has there been a longer-term effect? Can we expect the unemployment rates to return to their previous "natural" rates or have these natural rates themselves been affected by the crisis? Models of hysteresis in the unemployment rate predict that there may be permanent effects of at least some shocks to the unemployment rates. Examples are the insider-outsider theory and the hypothesis that there are scarring effects on the long-term unemployed during prolonged increases in the unemployment rate.

In this paper, we address the above questions by estimating time series for the natural rates of unemployment for the four Asian NIEs. ${ }^{2}$ We then examine the natural-rate estimates for the presence of long-term shifts at the time of the crisis and evaluate the differences between the actual and natural rates. Our method for estimating the natural rates is based on the structural vector autoregressive (SVAR) model of Blanchard and Quah (1989). It involves estimating a two-variable VAR and restricting it to allow us to identify supply and demand shocks. Within this framework we define the natural rate as the rate of unemployment that would have prevailed had there been no demand shocks.

The structure of the paper is as follows. In the next section we provide important background information on the labor markets of the NIEs and the way in which they have been affected by the crisis, including in our discussion material on historical, cultural and institutional factors, which will be important for the interpretation of our empirical results. The following section (section 3) will discuss and justify our definition of the natural rate of unemployment and set out the model we use to implement our definition. The data we use are reported and evaluated in section 4 and results are presented in section 5 . Conclusions are presented in the final section.

\footnotetext{
${ }^{2}$ We have been able to find very little empirical research on the natural rate of unemployment for the four Asian NIEs. Wong, Liu and Siu (1991) report estimates of the natural rate of unemployment for Hong Kong using Okun's Law that relates the output gap to cyclical unemployment. They estimated the natural rate of unemployment for Hong Kong at 2.6 percent. This, however, is only a single estimate and therefore not able to tell us whether the natural rate has shifted in response to the crisis.
} 


\section{Financial crisis and labor markets in Asian NIEs}

In this section we examine the labor market of each of our four NIEs in turn, discussing both its recent performance as well as its historical, cultural and institutional features, which are important for the interpretation of the results we obtain later in the paper.

\section{i. Hong Kong ${ }^{3}$}

The contagion effect of the financial crisis caught Hong Kong off-guard when currency speculators attacked the Hong Kong dollar on 23 October 1997. While other Asian economies such as Korea, Malaysia, Indonesia, Taiwan and Thailand depreciated their currency by as much as 79 percent of the original value, Hong Kong maintained its link with the US dollar at $7.75 \mathrm{HKD} / \mathrm{USD}$. This brought about a sudden and substantial loss of competitiveness vis-à-vis its neighbors in competing goods and services. The sector that had been hit almost immediately and the hardest was the tourism industry with the number of visitor arrivals in the first half of 1998 declining sharply by 21 percent compared to the first half of 1997 (Liu, 1998, p. 18). Higher relative prices compounded with recessions in Japan and other Asian economies contributed to the sharp decline in the number of visitors to Hong Kong.

The Currency Board System in use in Hong Kong caused the interest rate to rise sharply each time the Hong Kong dollar was under speculative attack. Although the interest rate eventually fell, it stayed at a relatively high level even after the attack receded, leading to severe contractions in domestic demand for goods and services. Property and retail were the two hardest hit sectors that catered mainly to local demand. Prices of residential property fell by more than 50 percent in 1998. Prices of commercial properties fell even more sharply. ${ }^{4}$ It was obvious then that the bubble economy leading up to Hong Kong's changeover had burst. In 1998, Hong Kong's GDP growth fell to a negative growth (-5.1 percent) for the first time in its history. The unemployment rate soared to 4.7 percent at the same time.

It is perhaps ironic that Hong Kong had been facing a labor shortage since 1985. The increasingly tight labor market caused the real wage rate to maintain a

\footnotetext{
${ }^{3}$ A concise discussion of the impact of the financial crisis on Hong Kong's economy and the challenges that Hong Kong faces after the crisis can be found in Liu Pak-wai (1998). Edward K. Y. Chen (2000) provides a summary of Hong Kong's economic development leading up to the financial crisis.

${ }^{4}$ Property prices also fell because the government's proposal to sharply increase the supply of land after the changeover in order to bring down the extraordinarily high prices of properties at the time.
} 
steady growth after 1984 in all sectors, especially in business services. By 1990, Hong Kong's unemployment rate fell to a record low of 1.4 percent. Several factors combined to cause the tight labor market condition in the late 1980 s and most of the 1990s. The most important factor is the transformation of Hong Kong's economy from a manufacturing-oriented to a service-oriented economy. The opening of China in late 1970s saw Hong Kong manufacturers moving their labor-intensive, low-tech production to south China to take advantage of the abundant cheap labor there, leaving the front-end and back-end of manufacturing processes, such as sourcing, merchandizing, marketing and design in Hong Kong. Since most of the output produced by Hong Kong manufacturers in south China were re-exported through Hong Kong, it stimulated a fast growth in re-export trade in Hong Kong and a demand for supporting activities including transportation, storage, business services, insurance and trade financing (Liu, 1998, p. 2).

The growth of the labor force could not keep up with the growth of demand for labor. The growth of the labor force slowed down from an annual rate of 2.5 percent between 1981-85 to less than one percent in 1986-92. One principal cause of the labor shortage was the substantial fall in the participation rate for those who were aged between 15-19 and 20-24. Due to the rapid expansion of secondary and tertiary education in Hong Kong in the 1980s, many youngsters deferred entry into the labor force. Emigration also played a big role in explaining the reduction in labor supply. The number of emigrants was between 18,000 and 22,000 throughout the first half of the 1980s, but it increased sharply after the June 4 incident in 1989 in Beijing and reached a peak of 66,000 in 1992 . Emigration affected the service sectors most severely since most of the emigrants were employees of the service sectors. At the same time, the desire of the government to ease the labor shortage by introducing a labor importation scheme in 1992 was met with considerable political resistance (Liu, 1998, p. 9). Eventually, only about 27,000 workers were imported at the peak of the program.

Full employment in Hong Kong in the pre-crisis era was supported by the booming property sector and rapid growth of re-export trade. High wage growth and high inflation were the manifestations of such a booming economy. However, after the bubble burst in 1997 following the sudden collapse of the property market and the slowdown in the re-export trade, downward cost adjustments appeared to be too small and too slow to restore full employment in Hong Kong. In Table 2, we compare the 
changes in unit labor costs of the four Asian NIEs from 1996 to 2001. In the face of rising unemployment and declining demand, unit labor costs did not fall in 1997 and 1998 in Hong Kong as it did in the other three NIEs; instead, it rose by 5.1 and 8.5 percent, respectively in these two years. When it finally fell in 1999, it fell by only 3.1 percent compared to falls of 10.8 percent in Singapore and 6.2 percent in Korea. The downward stickiness of labor costs deterred investment further when corporate profits and prospects for future profits looked dim.

Table 2: Changes in Unit Labor Costs (percentage)

\begin{tabular}{|c|c|c|c|c|c|c|}
\hline Country & 1996 & $\mathbf{1 9 9 7}$ & $\mathbf{1 9 9 8}$ & $\mathbf{1 9 9 9}$ & $\mathbf{2 0 0 0}$ & $\mathbf{2 0 0 1}$ \\
\hline Hong Kong & 5.6 & 5.1 & 8.5 & -3.1 & -1.0 & 2.5 \\
\hline Korea & 5.1 & -8.2 & -7.8 & -6.2 & 1.4 & 1.7 \\
\hline Singapore & 0.6 & -0.2 & -0.6 & -10.8 & 1.3 & -4.4 \\
\hline Taiwan & -5.4 & -5.9 & -13.5 & -3.9 & 0.9 & -6.8 \\
\hline
\end{tabular}

Sources: Figures are taken from The Economist Intelligence Unit, 'Latest Country Analysis', various issues.

What appears to have worsened Hong Kong's unemployment situation after the crisis is the sudden reversal of the declining growth rate of the labor force in 1996. The growth rate of the labor force rose from less than one percent in 1986-92 to 4 percent in 1997 and to about 6 percent in the latter part of 1998. The return of the emigrants from foreign host countries to seek jobs in Hong Kong after 1997 and the increased number of legal immigrants from Mainland China were mainly responsible for the rise in the growth rate of the labor force. Coupled with falling demand and a pessimistic economic outlook following the crisis, the accelerated growth rate of the labor force raised the unemployment rate to a peak of 6.2 percent in 1999.

\section{ii. Singapore $e^{5}$}

Singapore weathered well the financial crisis of 1997-98, although it could not completely escape the contagion. GDP growth slowed down from 8 percent in 1997 to 0.4 percent in 1998. The unemployment rate rose from 1.8 percent to 3.3 percent for the same period. However, unlike its close neighbors such as Malaysia, Thailand and Indonesia, Singapore did not suffer extreme disruptions to its capital flows mainly because of its better financial position and regulations. For example, Singapore's M2

\footnotetext{
${ }^{5}$ For a concise evaluation of Singapore's performance over the financial crisis, the reader is referred to Siriwardana and Schulze (2000).
} 
to foreign reserves ratio (1.1 in 1996), an indicator of the vulnerability of the financial system to external shocks, was much lower than that of Malaysia (3.3), Thailand (5.7) and Indonesia (4.7) [International Monetary Fund, 1997]. As such, although the Singapore dollar depreciated 16 percent against the US dollar, it appreciated by about 20 percent against the ringgit and baht, and 60 percent against the rupiah (Siriwardana and Schulze, 2000, p. 234).

Much of Singapore's economic slowdown was caused by contagion of the crisis through trade linkages (Chia, 1998). Singapore accounts for around half of all intra-ASEAN trade. Its exports of communication, financial, transportation and tourism services are mostly to its ASEAN neighbors. Moreover, Singapore is a major source of direct foreign investment in the ASEAN countries. Given this unique role played by Singapore in the region, the financial crisis had a rippling effect on its economy. First, the income effect directly lowered the demand for Singapore's goods and services. Second, Singapore's international competitiveness was eroded by the increase of its prices relative to those of its trading partners in competing goods and services.

Not only did Singapore fare better than Hong Kong in the financial crisis, its employment also recovered sooner than Hong Kong. There are several key factors that could explain their different experiences. First, Hong Kong maintained its exchange rate parity with the US dollar, leading to high interest rates, a loss of international competitiveness and depressed demand. Second, in order to relieve cost burdens on companies struggling to survive, the Singapore government adopted a cost-cutting package, worth $\mathrm{S} \$ 10$ billion per year or about 7 percent of GDP. This package featured a 15 percent reduction in total wage costs through a 10-percentage point cut in employers' contribution to the Central Providence Fund (CPF) effective January 1999 and reductions in the variable components of wages. Other business costs such as foreign worker levies, land and factory rentals, charges for government services and vehicle-related costs were also cut (Ministry of Trade and Industry, 1998, p. 32). ${ }^{6}$

Another key factor that helped Singapore to alleviate its unemployment situation following the onset of the crisis is the sheer size of its foreign workforce.

\footnotetext{
${ }^{6}$ The Singapore government has tight control of the wage rate. The National Wage Council, a tripartite body set up in 1972 by the government, publishes guidelines for pay increase. Its guidelines are closely observed even though they are not mandatory.
} 
Foreign workers constituted about one-third of its labor-force growth between 1975 and 1979. In 1980, there were 80,293 foreign workers on employment passes (Saw, 1984, p. 26). The number increased to 150,000 in 1985 and to about 300,000 in 1990 or from about 12 percent of the labor force in 1985 to about 20 percent of the labor force in 1990. The government imposes a levy on employers who import foreign workers. The amount of levy per worker imposed is an instrument of industrial policy as well as of keeping the wage of the foreign workers in line with that of the local workers.

A large contingence of foreign workers often creates social unease, but it has an advantage of keeping the unemployment rate relatively low in Singapore when recessions hit. The majority of foreign workers are from neighboring countries such as Malaysia or Indonesia and they can only remain in the country if their employment passes are renewed periodically. During economic downturns when a surplus of workers appears, the government may decide to repatriate some of the foreign workers by not renewing their employment passes. The financial crisis of 1997-98 illustrates the effectiveness of this policy when Singapore's unemployment rate rose only by 2.6 percentage points from the third quarter of 1997 to the last quarter of 1998 compared to the 3.5 percentage-point increase experienced by Hong Kong and a 5.3 percentage-point by Korea for the same period.

\section{iii. Korea $^{7}$}

Korea is the largest Asian NIE with a population of around 47 million in 1999. It started out as an impoverished agrarian country after the devastating Korea War in 1959. The country experimented briefly with import-substitution after the War, but soon switched to export-promotion in the 1960s. Since then, Korea has maintained a remarkably high growth rate over a period of 40 years. Like Singapore, the Korean government has been actively involved in directing the course of development in the economy. Economic planning is best illustrated by the government's initiative in developing the heavy and chemical industries in the 1970s.

The financial crisis has severely shaken Korea's economy. Its GDP fell by 6.7 percent in 1998 despite a financial support package negotiated with IMF in December

\footnotetext{
${ }^{7}$ Much of the discussion in this section is borrowed from a recent OECD study (2000) that looks at the changes in the labor market in Korea after the financial crisis. Dipak Mazumbar (1994) provides a discussion of Korea's development, its labor market structure and wage determination.
} 
1997. In retrospect, the weaknesses that exposed the country to the crisis can be identified as low profitability and high debt levels of the corporate sector, combined with the poor functioning of the financial system and the large size of short-term foreign debt (OECD, 1999). As will be seen in the next section, the level of indebtedness was much higher in Korea than in Taiwan and this high indebtedness can be attributed to Korea's reliance on foreign capital to develop its heavy and chemical industries.

Korea's labor market was especially hard hit, in a marked contrast with the near full employment situation prevailing during 1990-97. The unemployment rate increased sharply from 2.5 percent in the second quarter of 1997 to 6.9 percent in the second quarter of 1998 to a peak of 7.8 percent in the first quarter of 1999 . The number of unemployed went up from 0.5 million before the crisis to 1.5 million in 1998 and 1.8 million in February 1999. Labor force participation rate fell by 1.5 percentage points in 1998 . The fall in the participation rate was particularly marked for people aged between 20-29 (a fall of 4.2 percentage points) and those aged 60 years and older (a fall of 3.3 percentage points).

Korean household incomes were dramatically lowered due to a large fall in nominal and real wages from 1997 to 1998 . Nominal and real wages fell by 2.5 percent and 9.3 percent, respectively, over the period. Most of the wage reductions took the form of reduced bonuses and overtime payments, while the basic wage recorded a slight increase of 3.7 percent in nominal terms, but a fall of 3.5 percent in real terms. The large fall in wages over the crisis period can be attributed to: (1) the structure of wages in Korea that determines pay largely by enterprise performance, (2) the small influence of trade unions and their moderate collective bargain power and (3) a 10 percent cut in the wages of civil servants.

Due to a large fall in nominal and real wages, unit labor costs fell by 8.2 percent in 1997, 7.8 percent in 1998 and 6.2 percent in 1999 as shown in Table 2. As a result of flexible wages, a significant depreciation of the won and a quick response by the government, Korea's recovery from the crisis has been strong, with an 11 percent growth rate in GDP in 1999 followed by 8 percent in 2000. Reduced wages and currency depreciation improved corporate profits and increased international competitiveness, leading to an export-led recovery. The unemployment rate had fallen to about 4.0 percent in the second quarter of 2000 and employment had increased by about 300,000 jobs by the end of 1999 . There is a strong indication that 
Korea has once again reached near full employment. However, most of the jobs created were in the service sector, which was the least affected by the financial crisis, while the recovery of construction has been slower. Given Korea's current reforms and structural changes, which were triggered by the crisis, it is unlikely that the country's unemployment rate will fall back to its pre-crisis level.

\section{iv. $\quad$ Taiwan $^{8}$}

Taiwan is the only NIE that has managed to escape the severe blow of the financial crisis. Unlike Hong Kong, Singapore and Korea, there was no drastic increase in the number of unemployed in Taiwan following the onset of the crisis in 1997. Taiwan maintained a GDP growth rate of 4.6 percent in 1998, 5.4 percent in 1999 and 6.0 percent in 2000, while its unemployment rate was relatively stable at 2.7 percent in 1998, 2.9 percent in 1999 and 3.0 percent in 2000. Although the unemployment rate increased only slightly, there were some signs of contagion of the crisis in Taiwan's labor market. The ratio of the number of openings to job applicants dropped from 2.47 in 1997 to 1.54 in 1999, reflecting a decreasing number of jobs available per job seeker. Taiwan's labor force participation rate also dropped slightly from 58.3 percent in 1997, to 58.0 percent in 1999 and 57.9 percent in 2000, implying a slight increase in the number of discouraged workers.

Why did Taiwan fare much better than South Korea in the crisis, despite the two countries' sharing many similarities? One explanation is that the level of indebtedness in Korea was much higher than that in Taiwan. Taiwan's foreign debt amounted to US\$1 billion in 1997, while Korea had a foreign debt of US\$110.3 billion in the same period (Wang, 2000, p. 149). This large indebtedness can be traced to Korea's development of its heavy and chemical industries in the 1970s. Secondly, capital account liberalization in the 1980s in the two countries led to quite different effects. In Korea, inward foreign investment was more in the form of portfolio investment than of direct foreign investment, whereas Taiwan's capital inflow was more in the form of direct foreign investment; the ratio of portfolio investment to direct foreign investment was 6.2 to 1 in Korea, but 1.7 to 1 in Taiwan

\footnotetext{
${ }^{8}$ Chen and $\mathrm{Ku}(2000)$ and Wang (2000) provide comparative studies on Taiwan and Korea relating to the financial crisis of 1997-98. Kao (1996) studies the labor market structure in Taiwan before the financial crisis and Schive (1998) examines Taiwan's economic role after the crisis. A study (in Chinese) by Jiang (1997) discusses the causes of Taiwan's increasing trend of unemployment rate since the early 1990s.
} 
(Chen and $\mathrm{Ku}, 2000$, p. 127). This phenomenon can be explained by the different industrial structures in the two countries. Unlike Taiwan's industrial structure, which is characterized by the presence of mostly export-oriented small- to medium-size enterprises, Korea is dominated by large industrial conglomerates- the chaebols. These chaebols receive highly subsidized loans from the government to oligopolize Korea's industries. As a result, there is little room for direct foreign investments in Korea. This kind of industrial structure leaves Korea vulnerable to external shocks.

It is interesting that Taiwan's unemployment rate had started to increase even before the financial crisis of 1997-98. It increased from 1.5 percent in 1993 to 2.6 percent in 1996 and has remained above the 2.5 percent mark ever since, a trend which caused concern both to Taiwan's policy-makers as well as academic researchers. There are several factors contributing to this increasing trend (Kao, 1996, p. 53). First, since the late 1980s, Taiwan's industries have been increasingly moving their labor-intensive, assembly-line production offshore to Southeast Asian countries, particularly to China more recently. As a result, Taiwan's manufacturing employment has been steadily declining from a peak of 1.5 million in 1987 to 1.0 million in 1995 or at a rate of 4.8 percent per year. The rapid growth of capitalintensive industries did not increase the demand for labor due to their highly automated production. The service sector also failed to grow fast enough to absorb all of the surplus labor. Second, the transition between university and employment appears to be a difficult process for many graduates, as is reflected by the higher unemployment rate among those who received college education compared to those who received only higher secondary, lower secondary or primary education. The failure of the higher education system to supply appropriately trained graduates to meet market demand has been criticized as a structural cause of unemployment. Third, there is still a shortage of labor for the so-called 3Ds (dirty, danger and difficult) jobs. Despite an increasing unemployment rate, the generally well educated local labor force is no longer willing to accept these 3Ds jobs, making importation of foreign labor necessary in recent years.

In sum, Taiwan's labor market has largely been spared any significant adverse effect of the Asian financial crisis. The increasing trend in the unemployment rate is due mostly to transformation of Taiwan's economy, which are unrelated to the crisis. Moreover, Taiwan's relationship with Mainland China also plays a crucial role in determining the economic environment in Taiwan, as illustrated by the missile crisis 
in 1996. Given its uncertain relationship with Mainland China and economic restructuring, there is increasing doubt that Taiwan's unemployment rate will fall back to below 2 percent.

\section{A model of the natural rate of unemployment}

Friedman was the first to introduce the concept of the natural rate of unemployment. In his famous 1968 Presidential Address to the American Economic Association, Friedman proposed the following definition:

\footnotetext{
"The natural rate of unemployment is the level which would be ground out by the Walrasian system of general equilibrium equations, provided that there is imbedded in them the actual structural characteristics of the labor and commodity markets, including market imperfections, stochastic variability in demands and supplies, the cost of gathering information about job vacancies and labor availabilities, the costs of mobility, and so on." (Friedman, 1968, p. 8).
}

Clearly, Friedman's definition is not operational as it stands. It poses several difficulties. One difficulty arises from the catchall "and so on", which appears at the end of his definition. It points out that the definition is incomplete, but it does not give any hint as to what the missing features might look like. Another difficulty of a more practical nature is that producing a numerical model that mimics the hypothetical economy underlying the definition is no easy task; and without such a model we have no basis for the natural-rate estimation. Because of these difficulties, Friedman's definition has never been used as a starting-point for estimating the natural rate.

Nevertheless, there have been many reports of natural-rate estimates for the industrialized countries. These natural-rate estimates were obtained using a wide variety of alternative definitions, which share a common feature with Friedman's definition. That is, they all define the natural rate as the hypothetical unemployment rate, which would be observed if certain conditions prevail in the economy. Among them, two alternative definitions have been most commonly used. The first one defines the natural rate as the unemployment rate that would have been observed over a particular period if the economy had been continuously in equilibrium (see, for example, Layard and Nickell, 1985, for the UK, Nickell and Jackman, 1991 for a number of OECD countries and Ooi and Groenewold, 1992, for Australia). The 
second one identifies the natural rate with the non-accelerating-inflation rate of unemployment (NAIRU), which is estimated within the context of a Phillips Curve (see, for example, Gordon, 1997, and Staiger, Stock and Watson, 1997, for the US and Crosby and Oleklans, 1998 and Gruen, Pagan and Thompson, 1999, for Australia).

In this paper, we propose to compute the natural rate for the Asian NIEs from a model, which uses a common feature of both the equilibrium and NAIRU approaches without the need to choose between them. To do this we use a model with minimal theoretical structure and argue that these two concepts of the natural rate share a common feature: the natural rate would be observed only after shocks to aggregate demand have completely worked their way through the economic system. Thus, our definition of the natural rate is the unemployment rate that would have been observed if demand shocks had been zero from time $-\infty$ to the end of the sample period being analyzed. ${ }^{9}$ The analytical tool we employ is a vector-autoregressive (VAR) model on which we impose a simple identification restriction based on Blanchard and Quah (1989). We use this structural VAR (SVAR) model to produce a quarterly time-series natural rate for each of the four Asian NIEs using data for the longest common sample period of 1982 to 2000 .

The definition is not complete until the term, "demand shocks" is properly defined. The precise meaning we give to this term is tied up with the procedure we use to generate our natural-rate series from the estimated SVAR model, a matter we now turn to.

We begin with a two-equation linear static macroeconomic model in real output and the unemployment rate:

$$
\begin{aligned}
& b_{11}(0) u_{t}+b_{12}(0) y_{t}=b_{10}+\varepsilon_{1 t} \\
& b_{21}(0) u_{t}+b_{22}(0) y_{t}=b_{20}+\varepsilon_{2 t}
\end{aligned}
$$

where $y_{t}$ and $u_{t}$ represent real output and the unemployment rate and $\varepsilon_{1}$ and $\varepsilon_{2}$ random variables included to capture exogenous influences on the two endogenous variables.

\footnotetext{
${ }^{9}$ For an application of this definition to Australian data see Groenewold and Hagger (2000).
} 
The model is similar to that of Blanchard and Quah (1989) who motivate its form by starting with a four-equation macro model (aggregate demand, employment, wage- and price-setting equations) plus autoregressive processes for the money supply and productivity as well as a definition of the unemployment rate. They reduce this model to two equations in $y$ and $u$ and capture the exogenous variables as well as the random error terms of the autoregressive processes in the random variable $\varepsilon_{1}$ and $\varepsilon_{2}$. We identify $\varepsilon_{1}$ as a demand shock and $\varepsilon_{2}$ as a supply shock. The demand shock therefore captures the effects of both monetary and fiscal variables while the supply shock captures the effects of variables such as labor productivity and the labor force.

To enable the model to capture the interactions in an actual economy, we make it dynamic by adding lagged values of $u$ and $y$ to the right-hand sides of the two equations in (1). This gives:

$$
\begin{aligned}
b_{11}(0) u_{t}+b_{12}(0) y_{t} & =b_{10}+b_{11}(1) u_{t-1}+\ldots+b_{11}(p) u_{t-p} \\
& +b_{12}(1) y_{t-1}+\ldots+b_{12}(p) y_{t-p}+\varepsilon_{1 t} \\
b_{21}(0) u_{t}+b_{22}(0) y_{t} & =b_{20}+b_{21}(1) u_{t-1}+\ldots+b_{21}(p) u_{t-p} \\
& +b_{22}(1) y_{t-1}+\ldots+b_{22}(p) y_{t-p}+\varepsilon_{2 t}
\end{aligned}
$$

or, in matrix form:

$$
B(0) \underline{x}_{t}=\underline{b}_{0}+B(L) \underline{x}_{t-1}+\underline{\varepsilon}_{t}
$$

where $\mathrm{L}$ is the lag operator, $L^{j} \underline{x}_{t} \equiv \underline{x}_{t-j}$ and

$$
\begin{aligned}
& B(0) \equiv\left[\begin{array}{ll}
b_{11}(0) & b_{12}(0) \\
b_{21}(0) & b_{22}(0)
\end{array}\right], \quad \underline{b}_{0} \equiv\left[\begin{array}{l}
b_{10} \\
b_{20}
\end{array}\right], \quad \underline{x}_{t} \equiv\left[\begin{array}{l}
u_{t} \\
y_{t}
\end{array}\right] \\
& B(L) \equiv B(1)+B(2) L+B(3) L^{2}+. .+B(p) L^{p-1} \\
& B(j) \equiv\left[\begin{array}{ll}
b_{11}(j) & b_{12}(j) \\
b_{21}(j) & b_{22}(j)
\end{array}\right], \quad \underline{\varepsilon}_{t} \equiv\left[\begin{array}{l}
\varepsilon_{1 t} \\
\varepsilon_{2 t}
\end{array}\right]
\end{aligned}
$$

Recall that our definition of the natural rate of unemployment is that rate which would have been observed in the absence of demand shocks. Thus, we wish to use (3) to compute the natural rate as the value that $u$ would have taken over the sample period if the demand shock, $\varepsilon_{1}$, had been zero and the supply shock, $\varepsilon_{2}$, had taken its historical values. This computation uses the moving average (MA) form of the model:

$$
\underline{x}_{t}=\underline{c}_{0}+C(L) \underline{\varepsilon}_{t}
$$


where $C(L) \equiv(B(0)-B(L) L)^{-1}$ and $\underline{c}_{0} \equiv C(L) \underline{b}_{0}$.

The MA form cannot be used as it stands because we cannot compute the coefficient matrices $\mathrm{C}(\mathrm{L})$ and the structural errors $\varepsilon_{1}$ and $\varepsilon_{2}$ since the model from which they are derived, equation (3), cannot be estimated as it stands. This is clear from inspection since the two equations in (3) are observationally equivalent and therefore not identified. There are various ways of overcoming this identification problem and we focus on the method proposed by Blanchard and Quah (1989).

We start by noting that the model is estimated in the VAR form of the structural model:

$$
\underline{x}_{t}=\underline{a}_{0}+A(L) \underline{x}_{t-1}+\underline{e}_{t}
$$

where $\underline{a}_{0} \equiv B(0)^{-1} \underline{b}_{0}, A(L) \equiv B(0)^{-1} B(L)$ and $\underline{e}_{t} \equiv B(0)^{-1} \underline{\varepsilon}_{t}$. From a comparison of (4) and (5):

$$
\underline{e}_{t}=C(0) \underline{\varepsilon}_{t}, \text { for all t. }
$$

Hence once we have the four elements of $C(0)$ we can derive a series for both $\varepsilon_{1}$ and $\varepsilon_{2}$ from series for $e_{1}$ and $e_{2}$ which are estimated as the residuals from the VAR, (5). Knowledge of $\mathrm{C}(0)$ also permits the computation of all the $\mathrm{C}(\mathrm{L})$ matrices in (4). To show this, first write the VAR in MA form as:

$$
\underline{x}_{t}=d_{0}+D(L) \underline{e}_{t}
$$

where $D(L) \equiv(I-A(L) L)^{-1}$ and $d_{0} \equiv D(L) a_{0}$. The values of the $\mathrm{D}(\mathrm{L})$ matrices can be computed from the estimated VAR coefficients using the relationship that $\mathrm{C}(\mathrm{k})=$ $\mathrm{D}(\mathrm{k}) \mathrm{C}(0)$ which follows from the substitution of (6) into (7) and a comparison of the result with (4).

Hence, if we can identify $\mathrm{B}(0)$ or $\mathrm{C}(0)\left(=\mathrm{B}(0)^{-1}\right)$ we can move from the estimated VAR, (5), to a numerical form of the MA version of the structural model. Identification therefore requires four restrictions in the case of our two-variable model. The four restrictions used to identify $\mathrm{C}(0)$ are then as follows. The first two are normalization restrictions: the variance of each of $\varepsilon_{1}$ and $\varepsilon_{2}$ is set at 1 . The third restriction is that the structural errors have a zero covariance. The final restriction is based on the assumption that the demand shock has only a temporary effect on y but that the supply shock has a permanent effect on y. Neither shock has a permanent effect on $u$ since Blanchard and Quah found $u$ to be stationary while $y$ was found to be I(1). 
These four restrictions result in four (non-linear) equations in the four elements of $\mathrm{C}(0)$. Once these equations have been solved to produce estimates of the elements of $C(0)$, all the elements of equation (4) can be obtained from the estimated VAR model and its residuals. ${ }^{10}$

In summary, the model uses data on just two variables - real output and the unemployment rate - and uses the former to decompose the latter into that component driven by supply shocks (the natural rate) and that part driven by demand shocks. The decomposition is based on a model in which real output is non-stationary and the unemployment rate is stationary - both of these accord with our priors since real output is likely to be subject to a (stochastic) trend based on population and productivity growth whereas the unemployment rate, being a percentage of the total labor force, is bounded between 0 and 100 and, realistically, by much narrower bounds and therefore could be expected eventually to return to a given level following a shock, but possibly subject to structural shifts.

\section{The data}

Data for the unemployment rate and real GDP were used for each of the four countries. We chose the largest sample period common to all four countries. Data were used at a quarterly frequency since generally GDP data are available only at this frequency. The longest common sample period was 1986:1-2000:2. Singapore unemployment rate figures were not available before 1986:1 at a quarterly frequency although earlier data were available on an annual basis. By interpolating the annual data for the period 1982-1986 we were able to extend the sample to start in 1982:3. We interpolated by assuming the annual change in the unemployment rate to be evenly spread over four quarters of the year in question. Thus, finally, our data ran from 1982:3 to 2000:2.

All data were used in seasonally-adjusted form since we wished to abstract from seasonal fluctuations, given our focus on the long-run underlying unemployment rate. Where data were unavailable on a seasonally-adjusted basis from the country's official statistical agency, we adjusted the data using an exponential smoothing procedure which automatically chose whether to include a trend and whether to use

\footnotetext{
${ }^{10}$ For a detailed exposition of the estimation and simulation of a two-variable SVAR of the B-Q type see Enders (1995), Chapter 5.
} 
additive or multiplicative seasonal factors. The series seasonally adjusted in this way were real GDP for Hong Kong and the unemployment rate for Korea.

Before estimating the model, we tested the data for stationarity both as a standard preliminary econometric procedure and because the model has implications for stationarity as set out at the end of the previous section - the model's scheme for identifying demand and supply shocks is based on the plausible assumption that the unemployment is stationary and that the (log) of real GDP is non-stationary.

Table 3 reports $\mathrm{ADF}$ tests for stationarity of the two variables for various lags in the " $\mathrm{ADF}$ equation" - we felt that a maximum of four was sufficient given that quarterly data were used. ${ }^{11}$ The results in the table show quite clearly that neither variable is stationary using the $\mathrm{ADF}$ test based on conventional critical values. The outcomes are not dependent on the lag length. This conclusion is not unexpected for $y$ given results for other countries and other time periods reported in the literature.

Table 3: Stationarity: ADF Tests

\begin{tabular}{|l|c|c|c|c|c|c|}
\hline \multirow{2}{*}{ Country } & \multirow{2}{*}{ Variable } & \multicolumn{5}{|c|}{ Lags } \\
\cline { 3 - 7 } & $\mathbf{0}$ & $\mathbf{1}$ & $\mathbf{2}$ & $\mathbf{3}$ & $\mathbf{4}$ \\
\hline HK & $\mathbf{u}$ & -0.9750 & -1.3625 & -1.3953 & -2.2291 & -2.4528 \\
\hline HK & $\mathbf{y}$ & -2.1089 & -1.9242 & -2.3711 & -2.1461 & -2.4332 \\
\hline Singapore & $\mathbf{u}$ & -1.1907 & -1.5838 & -1.8160 & -2.2184 & -1.9132 \\
\hline Singapore & $\mathbf{y}$ & -1.7675 & -2.1502 & -2.4775 & -3.1463 & -2.7293 \\
\hline Sth Korea & $\mathbf{u}$ & -1.3632 & -2.6690 & -2.8372 & -2.1968 & -2.4917 \\
\hline Sth Korea & $\mathbf{y}$ & -1.2281 & -1.5255 & -1.5533 & -1.7271 & -1.3923 \\
\hline Taiwan & $\mathbf{u}$ & -1.5300 & -1.5457 & -1.6694 & -1.6563 & -1.8683 \\
\hline Taiwan & $\mathbf{y}$ & -0.2409 & -0.7394 & -0.9320 & -0.8583 & -1.0754 \\
\hline
\end{tabular}

Notes: (1) $\mathrm{u}=$ unemployment rate, $\mathrm{y}=\log$ of real GDP;

(2) the ADF equation for $y$ includes a trend term and the equation for $u$ does not;

(3) the $5 \%$ critical value for the test statistic is -2.9048 for u and -3.4626 for $y$.

However, the results are somewhat surprising for the unemployment rate since, as we have pointed out earlier, $\mathrm{u}$ is bounded by 0 and 1 so that it cannot wander about completely arbitrarily. Further, other studies such as Blanchard and Quah (1989) find that $u$ is stationary for the US. Our finding of non-stationarity may be the

\footnotetext{
${ }^{11}$ See Dickey and Fuller (1981).
} 
result of applying the tests for a long-run property such as stationarity to a relatively short data series over a period where there have been major structural changes in the labor market, a situation which Perron (1989) first argued could seriously bias the results of standard tests for a unit root. This is especially important in the present application since our maintained hypothesis is that there has been a structural break in the unemployment rate due to the crisis of $1997 / 98$. The application of the Perron test including a structural break requires the precise identification of the break point which may be different for different countries and, instead, we applied Zivot and Andrews' (1992) tests for a unit root in the presence of a break in mean and/or in trend at an indeterminate point in the sample. The results are in Table 4.

Table 4: Stationarity Tests for u: Zivot and Andrews (1992)

\begin{tabular}{|l||c|c||c|c||c|c||}
\hline \multirow{2}{*}{\multicolumn{1}{|c||}{ Country(lag) }} & \multicolumn{2}{c||}{ Break in mean } & \multicolumn{2}{c|}{ Break in trend } & \multicolumn{2}{c||}{ Break in mean and trend } \\
\cline { 2 - 7 } & Statistic & Break & Statistic & Break & Statistic & Break \\
\hline \hline HK (1) & -4.0771 & $1998: 1$ & -3.7511 & $1997: 4$ & -3.0728 & $1988: 3$ \\
\hline HK (2) & -4.0174 & $1998: 1$ & -3.6947 & $1997: 4$ & -3.0874 & $1988: 3$ \\
\hline HK (3) & -4.5028 & $1998: 1$ & -4.3382 & $1997: 4$ & -4.1410 & $1988: 3$ \\
\hline HK (4) & -4.7464 & $1998: 1$ & -4.5787 & $1997: 4$ & -4.7153 & $1988: 3$ \\
\hline \hline Sing (1) & -3.0013 & $1987: 1$ & -3.9732 & $1987: 1$ & -3.7690 & $1987: 1$ \\
\hline Sing (2) & -3.0808 & $1987: 1$ & -4.0135 & $1983: 1$ & -3.7699 & $1987: 1$ \\
\hline Sing (3) & -3.4328 & $1986: 4$ & -4.0219 & $1986: 4$ & -3.7605 & $1986: 4$ \\
\hline Sing (4) & -3.2640 & $1987: 1$ & -3.6352 & $1987: 1$ & -3.7796 & $1992: 1$ \\
\hline S Korea (1) & -4.7904 & $1997: 4$ & -6.2235 & $1997: 4$ & -5.9594 & $1998: 1$ \\
\hline S Korea (2) & -5.3811 & $1997: 4$ & -7.6802 & $1997: 4$ & -5.7337 & $1998: 1$ \\
\hline S Korea (3) & -4.4574 & $1997: 4$ & -6.9338 & $1997: 4$ & -3.8781 & $1995: 1$ \\
\hline S Korea (4) & -4.7572 & $1997: 4$ & -7.5611 & $1997: 4$ & -4.5518 & $1995: 4$ \\
\hline \hline Taiwan (1) & -2.4419 & $1995: 4$ & -4.0011 & $1986: 2$ & -3.8991 & $1986: 2$ \\
\hline Taiwan (2) & -2.5678 & $1995: 4$ & -4.0111 & $1986: 2$ & -3.8546 & $1986: 2$ \\
\hline Taiwan (3) & -2.5784 & $1995: 4$ & -3.7887 & $1986: 2$ & -3.4688 & $1986: 2$ \\
\hline Taiwan (4) & -2.7142 & $1995: 4$ & -3.9498 & $1986: 2$ & -3.6655 & $1986: 2$ \\
\hline \hline
\end{tabular}

Note: The $5 \%$ critical values for the three tests are $-4.80,-4.42$ and -5.08 respectively.

The results reported in Table 4 indicate that the null hypothesis of nonstationarity is clearly rejected for Korea at most lags and for all three forms of the test. It is interesting that for almost all cases the optimal break date is at the end of 1997 or the beginning of 1998 which coincides exactly with the onset of the crisis. The nonstationarity null is also rejected at the 5\% level for Hong Kong for the case of a shift in trend and is also close to being rejected for a break in mean. Again, for both these breaks the optimal break date is the end of 1997 or the beginning of 1998 . There seems, therefore, to be clear evidence for Korea and Hong Kong that a definite break occurred in the process which generates the unemployment rate in late 1997 or early 
1998 and that, once these breaks are taken into account, the unemployment rate is stationary. The evidence for the other two countries is less clear-cut, however. In each case there is some weak evidence of stationarity if a break in trend is allowed. However, it is interesting that in these cases the optimal break date is in the mid1980s and therefore does not coincide with the crisis.

In a recent paper, Arestis and Mariscal (1999) test for unit roots while allowing for two breaks in level and/or in trend at unspecified points, using extensions of the Zivot and Andrews procedure proposed by Clemente, Montanes and Reyes (1998) and Lumsdaine and Papell (1997). They found that for a majority of OECD countries the unemployment rate was stationary when two breaks were allowed even though all countries' unemployment rates were found to be non-stationary using a standard ADF test. We therefore applied both tests to the unemployment rates for the four countries over our sample. The results (which we do not report ${ }^{12}$ ) confirm the outcomes of the Zivot and Andrews test - for Korea there is strong evidence of stationarity and for Hong Kong the unemployment rate is stationary in some cases. For both these countries the dominant break coincides with the crisis. There is no change in the conclusions we reached for Singapore and Taiwan - there is only weak evidence of stationarity and the optimal break does not coincide with the crisis.

We conclude, on the basis of the outcomes of the range of tests described, that in general the evidence for our four countries is not inconsistent with our theoretical prior that the unemployment rates are stationary and real GDP is non-stationary. We, therefore, proceed to estimate the model incorporating the Blanchard and Quah identifying restrictions.

\section{Model estimation}

Before the model can be estimated, the order of the VAR needs to be chosen. We do that on the basis of the Akaike Information Criterion (AIC), the Schwarz Bayesian Criteriod (SBC) and a $\chi^{2}$ test the lag length be reduced from four (the maximum number we entertain) to the number of lags in question. The values of the criteria and the probability values for the $\chi^{2}$ test are reported in Table 5 .

\footnotetext{
${ }^{12}$ They are available from the corresponding author on request.
} 
Table 5: Choice of VAR Iag length

\begin{tabular}{|c|c|c|c|c|c|c|}
\hline & & \multicolumn{5}{|c|}{ Lags } \\
\cline { 3 - 7 } Country & Criterion & $\mathbf{0}$ & $\mathbf{1}$ & $\mathbf{2}$ & $\mathbf{3}$ & $\mathbf{4}$ \\
\hline HK & AIC & 41.1010 & 137.3253 & 138.8269 & $139.9592^{*}$ & 139.9517 \\
\hline HK & SBC & 38.8669 & $130.6229^{*}$ & 127.6564 & 124.3204 & 117.8448 \\
\hline HK & $\chi^{\mathbf{2}}$ & 0.000 & 0.038 & 0.135 & 0.483 & -- \\
\hline Singapore & AIC & 76.0818 & 162.3174 & $164.5116^{*}$ & 162.0506 & 160.9076 \\
\hline Singapore & SBC & 73.8771 & $155.7034^{*}$ & 153.4881 & 146.7178 & 141.0654 \\
\hline Singapore & $\chi^{2}$ & 0.000 & 0.106 & 0.472 & 0.293 & - \\
\hline S. Korea & AIC & 53.3857 & 154.3925 & $159.4816^{*}$ & 156.6960 & 155.5404 \\
\hline S. Korea & SBC & 51.1810 & 147.7784 & $148.4581^{*}$ & 141.2632 & 135.6981 \\
\hline S. Korea & $\chi^{2}$ & 0.000 & 0.030 & 0.534 & 0.295 & -- \\
\hline Taiwan & AIC & 203.7366 & 296.4855 & 297.9382 & $298.0993^{*}$ & 269.1437 \\
\hline Taiwan & SBC & 201.7366 & $289.1576^{*}$ & 285.7249 & 281.0008 & 274.1599 \\
\hline Taiwan & $\chi^{2}$ & 0.000 & 0.053 & 0.196 & 0.455 & -- \\
\hline
\end{tabular}

Note: an * denotes a row maximum.

As is common in the choice of lag length, there is some conflict between the indications given. For Hong Kong the AIC suggests a lag length of 3 while the SBC suggests 1 . A lag length of 1 is rejected by the $\chi^{2}$ test at the $5 \%$ significance level. Thus possible acceptable lag lengths for Hong Kong are 1,2 and 3. We experimented with both 1 and 3 but report results only for lag 1 since the general characteristics of the resulting series for the natural rate are not greatly affected by the choice, especially at the end of the sample, which we are particularly interested in. In the case of Singapore the main choice is between 1 and 2 lags. The $\chi^{2}$ test did not reject the reduction of lags from 4 to 1 at the $5 \%$ level and we therefore estimated the model with a single lag. For Korea all three criteria agree that a lag of 2 is appropriate and the results reported below therefore incorporate two lags. Finally, the criterion values reported in Table 5 for Taiwan conflict with the AIC suggesting a lag of 3 while the SBC suggests that 1 lag is optimal. Since the $\chi^{2}$ test cannot reject the reduction of lags from 4 to 1 , we estimated the model for Taiwan with only a single lag.

Once the lag length had been chosen the models were estimated by OLS and the Blanchard and Quah restrictions imposed on them. The resulting restricted models were then simulated to produce series for the natural rate: the unemployment rate which would have obtained if the demand shocks had been zero for the entire sample period. The resulting natural rate series are reported and compared to the unemployment rates actually observed in the following section. 


\section{Results and discussion}

Our results are pictured in Figure 1. The behavior of the natural rates differs considerably across countries. For two of the four countries in our sample, Hong Kong and Taiwan, the natural rate has varied very little over the two decades. For both of these countries there appears to have been no effect of the crisis on the underlying natural rate of unemployment. The sharp rise in the measured rate in Hong Kong must therefore reflect a rise in demand-deficient unemployment. On the other hand, as we have discussed in an earlier section, the experience in Taiwan is that there was little effect of the crisis on the measured rate of unemployment with the unemployment rate beginning to rise from a very low base in 1995 and stabilizing at a level of around $2.5-3 \%$ by the time the crisis hit the rest of the region.

The experience in the other two countries was quite different. In Korea there have been regular fluctuations in the natural rate of unemployment since the late 1980 s, the last of which coincided with the crisis of 1997-98. While the natural rate seems to have stabilized at around 3.6\%, this is still higher than the period preceding the crisis when its average level was approximately $3.2 \%$. Finally, the most dramatic results are those for Singapore. The results reported in Figure 1 suggest that over the sample period most of the fluctuations in the actual unemployment rate in Singapore have reflected changes in the underlying natural rate rather than demand fluctuations. If we concentrate on the $1990 \mathrm{~s}$, the natural rate has been relatively stable at a level just over $2 \%$ but risen to a level almost twice as great starting in 1997 although there has been a fall since late 1998. Thus the unemployment rate at the end of the sample reflects a high natural rate, although given its behavior over the past two decades there are strong reasons to expect it to fall to historical levels over the next two to three years. 
Figure 1: Actual and Natural Unemployment Rates

(quarterly)
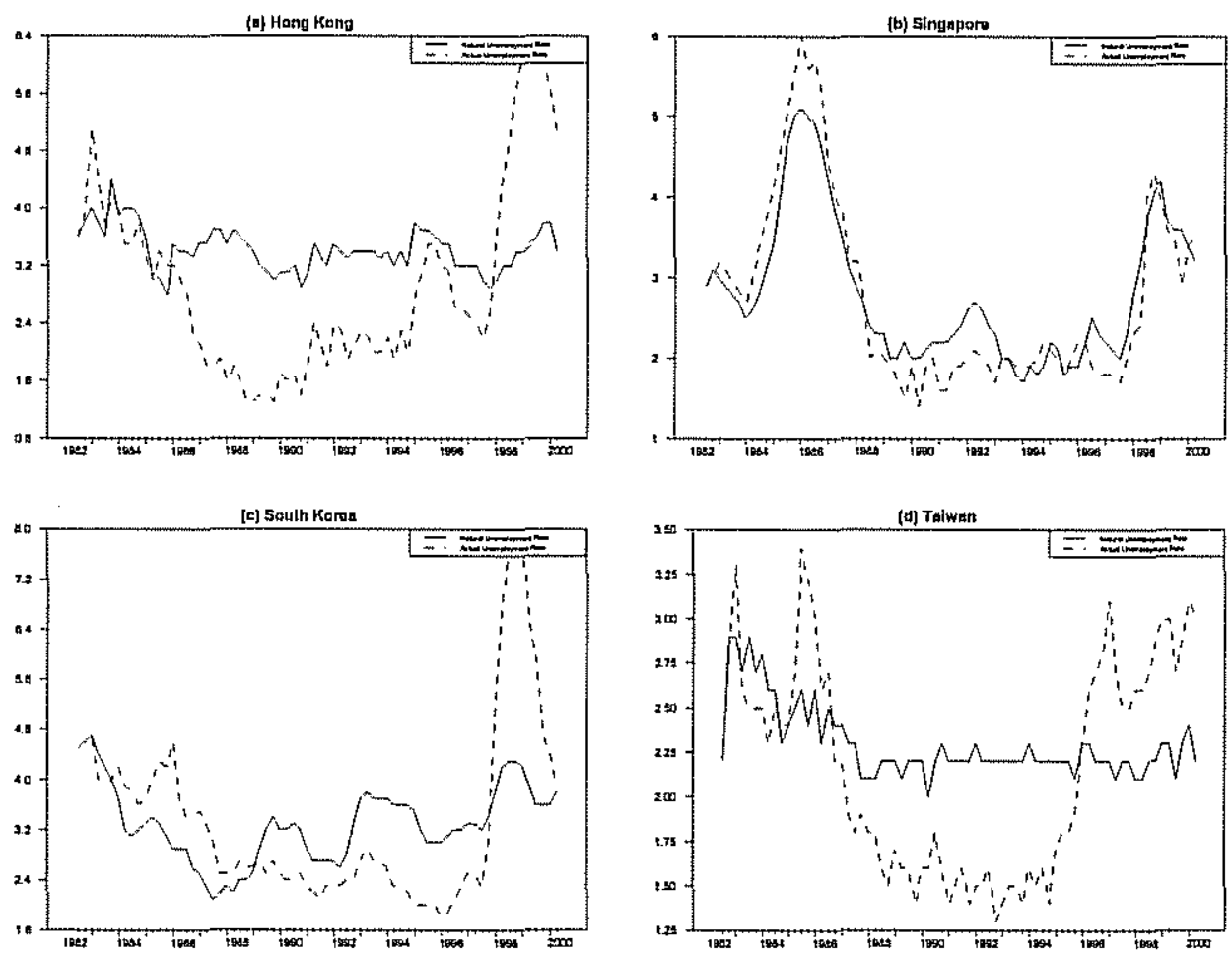

An important observation from a policy perspective is that a relatively large gap exists between the actual and natural rate in Hong Kong and Taiwan, but not in Korea and Singapore. This observation contains important information for decisionmakers in these respective economies. Singapore must concentrate on supply-side policies to get its natural rate down while Hong Kong and Korea need to implement demand-management to reduce the gap between the actual and natural rates.

\section{Conclusions}

This paper has set out to address the question of whether the rapid rise we observed in the unemployment rates in three of our four Asian NIEs (Hong Kong, Singapore, South Korea and Taiwan) in response to the Asian financial crisis of the late 1990s was a reflection of a rise in the underlying structural or natural unemployment rate or of a rise in the gap between the actual and natural rates.

We analyzed this question by estimating time series for the natural rates of unemployment for each of the four NIEs and comparing these with the observed rates. 
Our findings were that the behavior of unemployment rates differed considerably across these economies. In particular, the dramatic rise in the unemployment rate observed in Hong Kong and Korea was mainly the result of demand shocks rather than structural changes while in Singapore the unemployment rate rise reflected almost entirely a rise in the natural rate.

The policy implications of these differences are important since a high natural rate requires attention to structural factors while a rise in the gap between the actual and natural rates requires demand management policies. 
References

Arestis, P. and I. B. F. Mariscal (1999), 'Unit Roots and Structural Breaks in OECD Unemployment', Economics Letters, vol. 65, pp. 149-156.

Blanchard, O.J. and D. Quah (1989), 'The Dynamic Effects of Demand and Supply Disturbances', American Economic Review, vol. 79, pp. 655-673.

Chen, Edward K.Y. (2000). "The Economic Setting." In The Business Environment in Hong Kong, edited by Ng Sek Hong and David G. Lethbridge. Hong Kong: Oxford University Press, pp. 3-46.

Chen, T. J. and Y. H. Ku (2000). "Differing Approaches, Differing Outcomes: Industrial Priorities, Financial Markets, and the Crisis in Korea and Taiwan." In Weathering the Storm: Taiwan, Its Neighbors and the Asian Financial Crisis, edited by Peter C. Y. Chow and Bates Gill. Washington: Brookings Institution Press, pp. 111-146.

Chia Siow Yue (1998), 'The Asian Financial Crisis: Singapore Experience and Response', ASEAN Economic Bulletin, 15(3), pp. 297-308.

Clemente, J, A. Montanes and M. Reyes (1998), 'Testing for a Unit Root in Variables with a Double Change in the Mean', Economics Letters, vol. 59, pp. 175-182.

Crosby, M. and N. Olekahns (1998), 'Inflation, Unemployment and the NAIRU in Australia', Australian Economic Review, vol. 31, pp. 117-129.

Dickey, D.A. and W. A Fuller (1981), 'Likelihood Ratio Statistics for Autoregressive Time Series with a Unit Root', Econometrica, vol. 49, pp. 1057-1072.

Enders, W. (1995), Applied Econometric Time Series, Wiley, New York.

Friedman, M. (1968) 'The Role of Monetary Policy', American Economic Review, vol. 58, pp. 1-17.

Gordon, R.J. (1997), 'The Time-Varying NAIRU and its Implications for Economic Policy', Journal of Economic Perspectives, vol. 11, pp. 11-32.

Groenewold, N. and A. J. Hagger (2000),"The Natural Rate of Unemployment in Australia: Estimates from a Structural VAR", Australian Economic Papers, 39(2), pp. 121-137.

Gruen, D., A. Pagan and C. Thompson (1999), "The Phillips Curve in Australia", Journal of Monetary Economics, 44(2), October, pp. 223-258.

International Monetary Fund (1997), International Financial Statistics, Washington. Jiang (1997), "The Structure of Taiwan's Current Unemployment Problem and Its Solution", Taiwan Economic Forecast and Policy, 27(2), January, pp. 41-73.

Kao, Y. S. Carol (1996), "Labor Force Participation and Manpower Utilization in the Republic of China", Industry of Free China, 86(3), September, pp. 29-54.

Layard, R. and S. Nickell (1985), 'The Causes of British Unemployment', National Institute Economic Review, No.111, pp. 62-85.

Layard, R., S. Nickell and R. Jackman (1991), Unemployment: Macroeconomic Performance and the Labor Market, Oxford University Press, New York.

Liu Pak-Wai (1998), The Asian Financial Crisis and After Problems and Challenges for the Hong Kong Economy, Hong Kong: Occasional Paper No. 89, Hong Kong Institute of Asia-Pacific Studies, Chinese University of Hong Kong.

Lumsdaine, R.L. and D.H. Papell (1997), "Multiple Trend Breaks and the Unit-Root Hypothesis', Review of Economics and Statistics, vol. 79, pp. 212-218.

Mazumbar, Dipak (1994). "The Republic of Korea." In Labor Markets in an Era of Adjustment, Vol. 2 Case Studies, edited by Susan Horton, Ravi Kanbur and Dipak Mazumdar. Washington: The World Bank, pp. 535-583.

Ministry of Trade and Industry (1998), Report of the Committee on Singapore's Competitiveness, Singapore. 
OECD (1999), Economic Surveys: Korea, Paris.

OECD (2000), Pushing Ahead with Reform in Korea: Labor Market and Social Safety-Net Policies, Paris.

Ooi, Soon Huay and N. Groenewold (1992), 'The Causes of Unemployment in Australia 1996-1987', Australian Economic Papers, pp. 77-93.

Perron. P. (1989), 'The Great Crash, the Oil Price Shock, and the Unit Root Hypothesis, Econometrica, vol. 57, pp. 1361-1401.

Saw, Swee Hock (1984), The Labor Force of Singapore, Singapore: Census Monograph No. 2, Department of Statistics.

Schive, Chi (1998), 'Taiwan's Economic Role After the Financial Crisis', Industry of Free China, 88(12), December, pp. 107-140.

Siriwardana, Mahinda and Schulze David (2000), 'Singapore and the Asian Economic Crisis', ASEAN Economic Bulletin, 17(3), pp. 233-257.

Staiger, D., J.H. Stock and M.W. Watson (1997), 'The NAIRU, Unemployment and Monetary Policy", Journal of Economic Perspectives, vol. 11, pp. 33-49.

Wang, J. C. (2000). "Taiwan and the Asian Financial Crisis: Impact and Response." In Weathering the Storm: Taiwan, Its Neighbors and the Asian Financial Crisis, edited by Peter C. Y. Chow and Bates Gill. Washington: Brookings Institution Press, pp. 147-168.

Wong, Richard Y. C., Pak-Wai Liu and Alan K. F. Siu (1991), Inflation in Hong Kong: Patterns, Causes and Policies, Research Report, Business and Professionals Federation of Hong Kong.

Zivot, E. and Andrews, D. W. K. (1992), 'Further Evidence on the Great Crash, the Oil-Price Shock, and the Unit-Root Hypothesis', Journal of Business and Economic Statistics, vol. 10, pp. 251-70. 
Appendix: Actual and Natural Unemployment Rates

Table A1: Actual and Natural Unemployment Rates

\begin{tabular}{|c|c|c|c|c|c|c|c|c|}
\hline Date & HK: u & HK: $u^{*}$ & SN: u & SN: $u^{*}$ & SK: u & SK: $\mathbf{u}^{*}$ & TW: u & TW: $\mathbf{u}^{*}$ \\
\hline $82 / Q^{3}$ & 3.6 & 3.6 & 2.9 & 2.9 & 4.5 & 4.5 & 2.2 & 2.2 \\
\hline $82 / \mathrm{Q} 4$ & 3.9 & 3.8 & 3.1 & 3.1 & 4.6 & 4.6 & 2.9 & 2.9 \\
\hline $83 / \mathrm{Q} 1$ & 5.1 & 4.0 & 3.2 & 3.0 & 4.7 & 4.7 & 3.3 & 2.9 \\
\hline $83 / \mathrm{Q} 2$ & 4.4 & 3.8 & 3.1 & 2.9 & 4.0 & 4.4 & 2.6 & 2.7 \\
\hline $83 / Q^{3}$ & 3.8 & 3.6 & 3.0 & 2.8 & 3.9 & 4.2 & 2.5 & 2.9 \\
\hline $83 / \mathrm{Q} 4$ & 4.1 & 4.4 & 2.8 & 2.7 & 4.0 & 4.0 & 2.5 & 2.7 \\
\hline $84 / \mathrm{Q} 1$ & 4.0 & 3.9 & 2.7 & 2.5 & 4.2 & 3.7 & 2.5 & 2.8 \\
\hline $84 / \mathrm{Q} 2$ & 3.5 & 4.0 & 3.1 & 2.6 & 3.9 & 3.2 & 2.3 & 2.6 \\
\hline $84 / \mathrm{Q}$ & 3.5 & 4.0 & 3.4 & 2.8 & 3.8 & 3.1 & 2.5 & 2.6 \\
\hline $84 / \mathrm{Q} 4$ & 3.8 & 3.9 & 3.8 & 3.1 & 3.6 & 3.2 & 2.4 & 2.3 \\
\hline $85 / \mathrm{Q} 1$ & 3.3 & 3.6 & 4.1 & 3.4 & 3.7 & 3.3 & 2.4 & 2.4 \\
\hline $85 / \mathrm{Q} 2$ & 3.0 & 3.1 & 4.6 & 4.0 & 4.0 & 3.4 & 2.7 & 2.5 \\
\hline $85 / \mathrm{Q}^{3}$ & 3.4 & 3.0 & 5.1 & 4.7 & 4.3 & 3.3 & 3.4 & 2.6 \\
\hline $85 / \mathrm{Q} 4$ & 3.2 & 2.8 & 5.5 & 5.0 & 4.2 & 3.1 & 3.2 & 2.4 \\
\hline $86 / \mathrm{Q} 1$ & 3.2 & 3.5 & 6.0 & 5.1 & 4.6 & 2.9 & 3.0 & 2.6 \\
\hline $86 / \mathrm{Q} 2$ & 3.0 & 3.4 & 5.6 & 5.0 & 3.7 & 2.9 & 2.6 & 2.3 \\
\hline $86 / \mathrm{Q} 3$ & 2.8 & 3.4 & 5.7 & 4.9 & 3.4 & 2.9 & 2.7 & 2.5 \\
\hline $86 / \mathrm{Q} 4$ & 2.2 & 3.3 & 5.3 & 4.6 & 3.4 & 2.6 & 2.2 & 2.4 \\
\hline $87 / \mathrm{Q} 1$ & 2.1 & 3.5 & 4.4 & 4.2 & 3.5 & 2.5 & 2.2 & 2.4 \\
\hline $87 / \mathrm{Q}^{2}$ & 1.8 & 3.5 & 4.0 & 3.8 & 3.3 & 2.3 & 1.9 & 2.3 \\
\hline $87 / Q^{3}$ & 1.8 & 3.7 & 3.8 & 3.5 & 3.0 & 2.1 & 1.8 & 2.3 \\
\hline $87 / \mathrm{Q} 4$ & 1.9 & 3.7 & 3.2 & 3.1 & 2.5 & 2.2 & 1.9 & 2.1 \\
\hline $88 / \mathrm{Q} 1$ & 1.6 & 3.5 & 3.2 & 2.9 & 2.5 & 2.3 & 1.8 & 2.1 \\
\hline $88 / \mathrm{Q} 2$ & 1.8 & 3.7 & 2.8 & 2.7 & 2.5 & 2.2 & 1.8 & 2.1 \\
\hline $88 / Q^{3}$ & 1.6 & 3.6 & 2.0 & 2.4 & 2.7 & 2.4 & 1.6 & 2,2 \\
\hline $88 / \mathrm{Q} 4$ & 1.3 & 3.5 & 2.1 & 2.3 & 2.6 & 2.4 & 1.5 & 2.2 \\
\hline $89 / \mathrm{Q} 1$ & 1.3 & 3.4 & 2.0 & 2.3 & 2.6 & 2.5 & 1.7 & 2.2 \\
\hline $89 / \mathrm{Q} 2$ & 1.4 & 3.2 & 1.9 & 2.0 & 2.7 & 2.9 & 1.6 & 2.1 \\
\hline $89 / \mathrm{Q} 3$ & 1.4 & 3.1 & 1.7 & 2.0 & 2.5 & 3.2 & 1.6 & 2.2 \\
\hline $89 / \mathrm{Q} 4$ & 1.3 & 3.0 & 1.5 & 2.2 & 2.7 & 3.4 & 1.4 & 2.2 \\
\hline $90 / \mathrm{Q} 1$ & 1.7 & 3.1 & 1.9 & 2.0 & 2.5 & 3.2 & 1.6 & 2.2 \\
\hline 90/Q2 & 1.6 & 3.1 & 1.4 & 2.0 & 2.4 & 3.2 & 1.6 & 2.0 \\
\hline $90 / \mathrm{Q} 3$ & 1.7 & 3.2 & 1.9 & 2.1 & 2.4 & 3.3 & 1.8 & 2.2 \\
\hline $90 / \mathrm{Q} 4$ & 1.4 & 2.9 & 2.0 & 2.2 & 2.5 & 3.2 & 1.6 & 2.3 \\
\hline 91/Q1 & 1.8 & 3.1 & 1.6 & 2.2 & 2.3 & 2.9 & 1.4 & 2.2 \\
\hline $91 / \mathrm{Q} 2$ & 2.4 & 3.5 & 1.6 & 2.2 & 2.2 & 2.7 & 1.5 & 2.2 \\
\hline 91/Q3 & 2.1 & 3.3 & 1.9 & 2.3 & 2.1 & 2.7 & 1.6 & 2.2 \\
\hline $91 / \mathrm{Q} 4$ & 1.8 & 3.2 & 1.9 & 2.4 & 2.3 & 2.7 & 1.4 & 2.2 \\
\hline 92/Q1 & 2.4 & 3.5 & 2.0 & 2.6 & 2.3 & 2.7 & 1.5 & 2.3 \\
\hline $92 / \mathrm{Q} 2$ & 2.3 & 3.4 & 2.1 & 2.7 & 2.3 & 2.6 & 1.5 & 2.2 \\
\hline $92 / \mathrm{Q} 3$ & 1.9 & 3.3 & 2.0 & 2.6 & 2.4 & 2.8 & 1.6 & 2.2 \\
\hline $92 / \mathrm{Q} 4$ & 2.1 & 3.4 & 1.9 & 2.4 & 2.4 & 3.3 & 1.3 & 2.2 \\
\hline 93/Q1 & 2.3 & 3.4 & 1.7 & 2.3 & 2.7 & 3.7 & 1.4 & 2.2 \\
\hline $93 / \mathrm{Q}^{2}$ & 2.2 & 3.4 & 2.0 & 2.0 & 2.9 & 3.8 & 1.5 & 2.2 \\
\hline 93/Q3 & 2.0 & 3.4 & 2.0 & 2.0 & 2.7 & 3.7 & 1.5 & 2.2 \\
\hline $93 / \mathrm{Q} 4$ & 2.0 & 3.3 & 1.9 & 1.8 & 2.7 & 3.7 & 1.4 & 2.2 \\
\hline
\end{tabular}




\begin{tabular}{|l|l|l|l|l|l|l|l|l|} 
94/Q1 & 2.2 & 3.4 & 1.9 & 1.7 & 2.6 & 3.7 & 1.6 & 2.3 \\
\hline $94 / \mathrm{Q} 2$ & 1.9 & 3.2 & 1.9 & 1.9 & 2.3 & 3.6 & 1.5 & 2.2 \\
\hline $94 / \mathrm{Q} 3$ & 2.3 & 3.4 & 2.0 & 1.8 & 2.3 & 3.6 & 1.6 & 2.2 \\
\hline $94 / \mathrm{Q} 4$ & 2.0 & 3.2 & 2.2 & 1.9 & 2.2 & 3.6 & 1.4 & 2.2 \\
\hline $95 / \mathrm{Q} 1$ & 2.8 & 3.8 & 2.1 & 2.2 & 2.0 & 3.5 & 1.7 & 2.2 \\
\hline $95 / \mathrm{Q} 2$ & 3.1 & 3.7 & 2.0 & 2.1 & 2.0 & 3.2 & 1.8 & 2.2 \\
\hline $95 / \mathrm{Q} 3$ & 3.5 & 3.7 & 1.8 & 1.8 & 2.0 & 3.0 & 1.8 & 2.2 \\
\hline $95 / \mathrm{Q} 4$ & 3.5 & 3.6 & 2.0 & 1.9 & 2.0 & 3.0 & 1.9 & 2.1 \\
\hline $96 / \mathrm{Q} 1$ & 3.2 & 3.5 & 2.2 & 1.9 & 1.8 & 3.0 & 2.3 & 2.3 \\
\hline $96 / \mathrm{Q} 2$ & 3.1 & 3.5 & 2.2 & 2.2 & 1.9 & 3.1 & 2.6 & 2.3 \\
\hline $96 / \mathrm{Q} 3$ & 2.6 & 3.2 & 1.9 & 2.5 & 2.1 & 3.2 & 2.7 & 2.2 \\
\hline $96 / \mathrm{Q} 4$ & 2.6 & 3.2 & 1.8 & 2.3 & 2.3 & 3.2 & 2.8 & 2.2 \\
\hline $97 / \mathrm{Q} 1$ & 2.5 & 3.2 & 1.8 & 2.2 & 2.5 & 3.3 & 3.1 & 2.2 \\
\hline $97 / \mathrm{Q} 2$ & 2.4 & 3.2 & 1.8 & 2.1 & 2.5 & 3.3 & 2.7 & 2.1 \\
\hline $97 / \mathrm{Q} 3$ & 2.2 & 3.0 & 1.7 & 2.0 & 2.3 & 3.2 & 2.5 & 2.2 \\
\hline $97 / \mathrm{Q} 4$ & 2.5 & 2.9 & 2.0 & 2.3 & 3.0 & 3.4 & 2.5 & 2.2 \\
\hline $98 / \mathrm{Q} 1$ & 3.5 & 3.0 & 2.3 & 2.8 & 5.2 & 3.8 & 2.6 & 2.1 \\
\hline $98 / \mathrm{Q} 2$ & 4.4 & 3.2 & 2.4 & 3.2 & 6.9 & 4.2 & 2.6 & 2.1 \\
\hline $98 / \mathrm{Q} 3$ & 5.0 & 3.2 & 4.0 & 3.8 & 7.6 & 4.3 & 2.7 & 2.2 \\
\hline $98 / \mathrm{Q} 4$ & 5.7 & 3.4 & 4.3 & 4.1 & 7.6 & 4.3 & 2.9 & 2.2 \\
\hline $99 / \mathrm{Q} 1$ & 6.2 & 3.4 & 4.0 & 4.2 & 7.8 & 4.2 & 3.0 & 2.3 \\
\hline $99 / \mathrm{Q} 2$ & 6.1 & 3.5 & 3.6 & 3.7 & 6.5 & 3.9 & 3.0 & 2.3 \\
\hline $99 / \mathrm{Q} 3$ & 6.1 & 3.6 & 3.5 & 3.6 & 5.9 & 3.6 & 2.7 & 2.1 \\
\hline $99 / \mathrm{Q} 4$ & 6.0 & 3.8 & 2.9 & 3.6 & 4.7 & 3.6 & 2.9 & 2.3 \\
\hline $00 / \mathrm{Q} 1$ & 5.6 & 3.8 & 3.4 & 3.4 & 4.4 & 3.6 & 3.1 & 2.4 \\
\hline $00 / \mathrm{Q} 2$ & 5.0 & 3.4 & 3.5 & 3.2 & 3.9 & 3.8 & 3.0 & 2.2 \\
\hline No & & & 5.9 & & & & &
\end{tabular}

Notes: HK $=$ Hong Kong, $\mathrm{SN}=$ Singapore, $\mathrm{SK}=$ South Korea, $\mathrm{TW}=$ Taiwan, $\mathrm{u}=$ actual unemployment rate and $\mathrm{u}^{*}=$ natural unemployment rate. 